\section{Birlesik Dünya Arastırma Cypriot Journal of Educational BD-CENTER \\ Sciences}

Innovasyon ve Yayıneılık Merkezi
Volume 16, Issue 3, (2021) 1204-1216

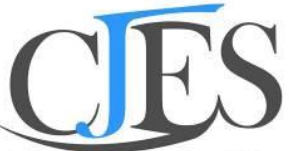

Cypriot Joumal of Educational Sciences

www.cjes.eu

\title{
Instrument performance self-efficacy perceptions of Music education students
}

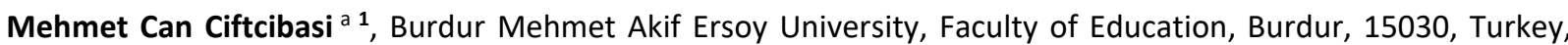
https://orcid.org/0000-0002-8825-1001

\section{Suggested Citation:}

Ciftcibasi, M, C. (2020). Instrument performance self-efficacy perceptions of Music education students. Cypriot Journal of Educational Science. 16(3), 1204-1216. https://doi.org/10.18844/cjes.v16i3.5841

Received from January 12, 2020; revised from April 15, 2021; accepted from June 01, 2021.

(C)2021 Birlesik Dunya Yenilik Arastirma ve Yayincilik Merkezi. All rights reserved.

\begin{abstract}
The aim of this research was to identify the instrument performance self-efficacy status of students in the music education department. The study group for the research comprised 121 students attending Mehmet Akif Ersoy University Faculty of Education, Department of Music Education. In order to identify the self-efficacy perceptions of students in the research, the "Self-Efficacy Scale Related to Instrument Performance" developed by Şeker (2016) was used. The model had a chi-square value 283.52, with 148 degrees of freedom. Investigation of the reliability of the scale found that the Cronbach alpha coefficient for the whole scale was .90 with correlation coefficient $r=.88, p<0.01$. When the instrument performance self-efficacy of students in the music education department was investigated, it was seen that male students have higher self-efficacy perception than female students. Additionally, students who had graduated from fine art high schools were surmised to have higher self-efficacy for instrument performance compared to those who had graduated from other high schools.
\end{abstract}

Keywords: Instrument performance; music education; self-efficacy.

* ADDRESS FOR CORRESPONDENCE: Mehmet Can, Çiftçibaşı, Burdur Mehmet Akif Ersoy University, Faculty of Education, Music Education Department, Burdur, Turkey 


\section{Introduction}

Social-cognitive theory assumes self-efficacy affects behaviour and environment and conversely is affected by them (Bandura, 1997). Self-efficacy also assists in determining how much effort people will put into an activity, how much they will press on when faced with obstacles, and how resistant they are when faced with negative situations (Schunk \& Pajares, 2009). Self-efficacy is defined as "beliefs about the ability to successfully apply the behaviour necessary to produce outcomes" (Bandura, 1977, cited by McCormick \& McPherson, 2003). Additionally, self-efficacy involves organizing and completing the necessary actions or skills to display competent performance. For example, self-efficacy in music performance does not just involve a good instrumentalist knowing his or her own ability, but also involves clear judgments about the skills required to perform in front of others like in a music exam or concert (McCormick \& McPherson, 2003). Externally graded performance exams, like those offered by Trinity College London and the Associated Board of the Royal Schools of Music, present a unique framework to investigate the self-efficacy perceptions of young musicians. These perceptions are important especially considering the possibility of fluctuations linked to external factors like the physical status and mood of the person, in addition to the nature of the task and social surroundings (Pintrich \& Schunk, 1996).

The instrument education lesson taught in the music education department can be regarded as shaping the self-efficacy beliefs of individuals related to personal experiences as the lesson is taught one-on-one, allows the opportunity for individuals to exhibit their skills, and includes musical performance with most instruments (Şentürk \& Bölek, 2019).

Instrument education lessons are carried out for one hour a week in the departments of music education. Students study for one hour a week with the instrument teacher, and the rest of the time they manage their instrument education on their own. During this process, students must proceed with appropriate strategies towards the target they have determined in order for them to perform their instrument studies efficiently (Şeker, 2014). Students should be aware of the perception of self-efficacy and benefit from this perception for efficient work.

In the relevant literature, there are many domestic and international studies on how musical selfefficacy is related to other structures in music. These studies examined the relationship between selfefficacy and musical performance in terms of different variables and in different study groups. McCormick and McPherson (2003) studied the role of self-efficacy when examining musical performance with structural equation analysis. As a result of this examination, they determined that the most important predictor of real performance in graded scoring used in music performance exams is self-efficacy. Nielsen (2004) determined the strategies used by 1st year students who received undergraduate music education in Norway during their individual studies and found that they generally used cognitive, metacognitive, and resource management strategies. He found that students with high self-efficacy used more cognitive and metacognitive strategies when trying to learn material compared to students with low levels. St. George (2006) conducted his research with 376 primary and secondary school students playing instruments in Australia. The study group consisted of two groups: students who were continuing with their instrument education (69\%) and students who had quit their instrument education (31\%). Serious differences emerged between these two groups in terms of musical background, musical emotion, application satisfaction, and self-efficacy levels. It was determined that the self-efficacy levels of the students who had quit their instrument education were very low compared to those who were continuing with their education. The researcher found that the self-efficacy perceptions of the students regarding their own learning processes were strongly related to instrument learning. Silverman (2008) stated that students' level of knowledge should be raised above musical technique and their self-efficacy levels should be increased by using constructivist and creative democratic learning processes in order to create and develop musical interpretations in students artistically and personally. Yıldırım (2009) investigated the effect of the Kodaly method on violin playing skill, self-efficacy perception, and attitudes towards violin playing in elementary school violin students. 
He determined that self-efficacy significantly affected the tendency to play violin dimension. Şeker and Bilen (2010) studied the effects of Orff-supported violin training on the perception of self-efficacy towards playing violin in children aged between 9 and 11 and determined that this training had positive effects on self-efficacy perception. Zelenak (2015) studied the scores of middle school and high school music students in the USA on the music performance self-efficacy scale (MPSES) and found that selfefficacy increased their musical ability scores.

Studies have also been conducted on the importance of self-efficacy in measuring musical performance and developing a self-efficacy measurement tool. McPherson and McCormick (2006) compared two different graded scoring measurement tools used during musical performance measurement. Self-efficacy perception is included in only one of these performance measurement tools, and the results of the study showed that self-efficacy was again the most important predictor of success in exams. Afacan (2008) developed a tool to measure the self-efficacy levels of teacher candidates in teaching music, Özmenteş (2011) developed a self-efficacy scale for music teaching, Gün and Yıldız (2014) developed a piano performance self-efficacy scale for music teacher candidates, Girgin (2015) developed an instrument performance self-efficacy scale consisting of 20 items and 3 subdimensions, and Şeker (2016) developed a self-efficacy scale for instrument performance. Şentürk and Bölek (2019) examined musical teacher candidates' instrument self-efficacy in terms of different variables and found that male candidates had higher levels of self-efficacy.

In the relevant literature, the self-efficacy perceptions of music educators/candidates and the relationship between these perceptions and different variables were studied. Thompson (2007) mentioned the beliefs of music educators about learning to teach music in his article. He focused on the search for new educational processes, the need to change and expand personal teaching schemes, and the importance of self-efficacy in this process by putting aside familiar practices in both the education of music education candidates and when they start their profession. Welch et al. (2009) mentioned the importance of classroom teachers' self-efficacy levels for singing and teaching songs in their study. Küçük (2011) studied the relationship between music teacher candidates' perceptions of self-efficacy regarding musical talent and their academic achievement. He determined that the music teacher candidates who have high self-efficacy beliefs are more ready and eager to learn and achieve greater academic success. Yokuş (2014) found that there is a positive significant relationship between selfefficacy and academic achievement when he examined the differentiation status of teacher candidates' education and teaching self-efficacy levels according to various variables. Özmenteş (2014) examined the relationship between music self-efficacy and self-esteem in high school and university-level vocational music education students. The results of the study indicated a positive significant relationship between self-efficacy and self-esteem, while male students had a higher musical self-efficacy level.

The research problem of the study was "What is the level of self-efficacy perceptions of the music education department students in their instrument performances?".

Within the framework of this problem, the answers to the following sub-problems were sought.

- Do the self-efficacy perception levels of the students of the music education department show a significant difference according to the variables of age, sex, individual instrument, and the type of high school graduated from?

- Do the self-efficacy perception levels of musical education students' instrument performances differ significantly according to the quality perception of their individual instruments?

- Do the self-efficacy perception levels of musical education students' instrument performances differ significantly according to their status of having performed a solo concert? 
- Do the self-efficacy perception levels of the musical education students in their instrument performances differ significantly according to their level of earning money through their individual instruments?

- Do the self-efficacy perception levels of the musical education students' instrument performances differ significantly according to the individual instrument course grade?

\section{Method}

This research, targeting investigation of the instrument performance self-efficacy perceptions of students in the music education department, was a descriptive study involving survey research. Research aiming to collect data with a range of tools like interview questions and tests in order to identify the features of a group is called survey research (Büyüköztürk et al., 2009).

\subsection{Study group}

The study group comprised 121 students attending Mehmet Akif Ersoy University, Faculty of Education, Music Education Department in the 2019-2020 educational year.

Table 1. Frequency and percentage distribution of demographic information for university students participating in the study

\begin{tabular}{|c|c|c|c|}
\hline Variable & Sub-variable & $f$ & $\%$ \\
\hline \multirow{4}{*}{ Year } & 1st year & 40 & 33.1 \\
\hline & 2nd year & 30 & 24.8 \\
\hline & $3 r d$ year & 27 & 22.3 \\
\hline & 4th year & 24 & 19.8 \\
\hline \multirow{3}{*}{ Age group } & $18-19$ & 32 & 26.4 \\
\hline & $20-21$ & 53 & 43.8 \\
\hline & $22-23$ & 36 & 29.8 \\
\hline \multirow{2}{*}{ Sex } & Male & 52 & 43.0 \\
\hline & Female & 69 & 57.0 \\
\hline \multirow{6}{*}{ Individual instrument } & 1st group & 37 & 30.6 \\
\hline & 2nd group & 39 & 32.2 \\
\hline & 3rd group & 20 & 16.5 \\
\hline & 4th group & 13 & 10.7 \\
\hline & 5 th group & 10 & 8.3 \\
\hline & Other & 2 & 1.7 \\
\hline \multirow{2}{*}{$\begin{array}{l}\text { High school of } \\
\text { graduation }\end{array}$} & Fine Arts High School & 67 & 55.4 \\
\hline & Other High School & 54 & 44.6 \\
\hline \multirow{3}{*}{$\begin{array}{l}\text { Perception of instrument } \\
\text { quality }\end{array}$} & $1-4$ & 11 & 9.1 \\
\hline & $5-7$ & 65 & 53.7 \\
\hline & $8-10$ & 45 & 37.2 \\
\hline Have you performed a & Yes & 46 & 38.0 \\
\hline \multirow[t]{2}{*}{ solo concert? } & No & 75 & 62.0 \\
\hline & 0 & 75 & 62.0 \\
\hline \multirow[t]{2}{*}{ Number of solo concerts } & $1-2$ & 20 & 16.5 \\
\hline & $2+$ & 26 & 21.5 \\
\hline Do you earn money with & Yes & 39 & 32.2 \\
\hline \multirow[t]{3}{*}{ your instrument? } & No & 82 & 67.8 \\
\hline & Less than 50 & 8 & 6.6 \\
\hline & $50-59$ & 11 & 9.1 \\
\hline \multirow[t]{3}{*}{ Instrument grades } & $60-69$ & 15 & 12.4 \\
\hline & $70-79$ & 34 & 28.1 \\
\hline & $80-89$ & 22 & 18.2 \\
\hline
\end{tabular}


The table shows that $33.1 \%$ of the university students participating in the research were 1 st year students, $24.8 \%$ were 2 nd year students, $22.3 \%$ were 3 rd year students, and $19.8 \%$ were 4 th year students. Of the students, $26.4 \%$ were in the $18-19$ year age group, $43.8 \%$ were in the $20-21$ year age group, $29.8 \%$ were in the $22-23$ year age group, $43 \%$ were male, and $57 \%$ were female. In terms of instrument groups, $30.6 \%$ were in the 1st group of instruments, $32.2 \%$ were in the 2 nd group, $16.5 \%$ were in the 3 rd group, $10.7 \%$ were in the 4 th group, $8.3 \%$ were in the 5 th group, and $1.7 \%$ were in the other instruments group (as the number playing other instruments was low, they were not included in the analysis for the hypothesis tests). Of the students, $55.4 \%$ had graduated from fine arts high schools and $44.6 \%$ from other high school types. Among the students participating in the research, $38 \%$ had given solo concerts, while $62 \%$ had never performed solo concerts, $16.5 \%$ had given solo concerts $1-2$ times, $21.5 \%$ had given solo concerts more than 2 times, and $32.2 \%$ earned money with their instrument. Among the students participating, $6.6 \%$ had an instrument lesson grade of 50 or lower, $9.1 \%$ of $50-59,12.4 \%$ of $60-69,28.12 \%$ of $70-79,18.2 \%$ of $80-89$, and $35.6 \%$ of $90-100$.

Table 2. Descriptive statistics for self-efficacy scale points for instrument performance, age, instrument sound quality, number of solo concerts, and final grade for instrument lessons of university students

\begin{tabular}{ccc}
\hline Variable & $\mathrm{x}$ & $\mathrm{sd}$ \\
\hline $\begin{array}{c}\text { Self-efficacy belief about } \\
\text { instrument performance }\end{array}$ & 6.75 & 1.675 \\
Mood felt during instrument & & 1.774 \\
studies & 6.18 & 1.992 \\
Modelling & 2.81 & 2.399 \\
Age & 20.96 & 1.938 \\
Instrument sound quality & 6.83 & 1.852 \\
Number of solo concerts & 1.11 & 16.644 \\
\hline
\end{tabular}

The table shows that the university students participating in the research had mean performancerelated self-efficacy points of $6.75 \pm 1.675$, mean points for mood felt during instrument work of $6.18 \pm 1.774$, and mean modelling points of $2.81 \pm 1.992$. The mean age of the students participating was $20.96 \pm 2.399$ years, mean instrument sound quality was $6.83 \pm 1.938$ points, mean number of solo concerts was $1.11 \pm 1.852$, and mean grade from the instrument lesson was $74.51 \pm 16.644$ points.

\subsection{Data collection tools}

The data in the study were obtained using the "Self-Efficacy Scale for the Candidate Music Teacher" developed by Şeker (2016) and the "Personal Information Form" developed by the researcher.

\subsubsection{Personal information form}

This form, developed by the researcher, gathered demographic information of the students of the department of music education such as sex, age, individual instrument, and the type of school graduated from, as well as questions about the variables in the sub-problems. These include the students' perception of the sound quality of their instrument, the status of giving a solo concert, the status of earning money with the instrument, and the final individual instrument lesson exam grade.

\subsubsection{Self-Efficacy scale for the candidate music teacher}

The scale includes 19 items, six of which are negative and 13 of which are positive. The scale has three sub-dimensions: "Self-efficacy about performance", "Emotional states during instrument 
training", and "Modelling". The reliability coefficients of the sub-dimensions of the scale were calculated as 86,76 , and 61 , respectively. The chi-square value of the model is 283.52 and the degree of freedom is 148 . When the reliability of the scale is examined, the Cronbach-alpha coefficient of the whole scale is .90 and the correlation coefficient is $r=.88, p<0.01$. As a result of the confirmatory factor analysis of the scale, it was determined that the model created was $x 2=283.52 \mathrm{df}=148$ and the $x 2 / \mathrm{df}$ ratio (1.91) was found to be evidence that the model showed a good fit. Later, similar scale validity analyses of the developed scale were performed and it was found that there was a strong positive correlation $(r=.651$, $p<0.01$ ) regarding the total scores of both scales (Şeker, 2016).

\subsection{Analysis of data}

SPSS 22.0 was used to analyze the data obtained. The scale data first were tested for reliability, which gave a Cronbach alpha internal consistency coefficient for the scale of .888 for the performance-related self-efficacy belief sub-dimension, .754 for the mood felt during instrument work, .906 for the modelling sub-dimension, and .717 for the whole scale. One-sample Kolmogorov-Smirnov analysis was applied to check the normality assumption and the data related to sub-dimensions and total points were identified to display normal distribution. Comparisons of scale points according to demographic variables with two categories used the independent $t$ test, while comparison of scale points with three or more categories used one-way ANOVA. For the ANOVA, Tukey's test was applied post hoc. Pearson correlation analysis and multiple linear regression analysis were used to investigate the effect of year of education, age, sound quality of instrument, number of solo concerts, and grade for the instrument lesson on scale total points.

\section{Findings}

Table 3. Comparison of self-efficacy related to instrument performance scale points of university students according to the age group variable

\begin{tabular}{ccccccc}
\hline Subscale & $\begin{array}{c}\text { Age } \\
\text { group }\end{array}$ & $\mathrm{n}$ & $\mathrm{x}$ & $\mathrm{sd}$ & $\mathrm{f}$ & $\mathrm{p}$ \\
\hline Self-efficacy belief & $18-19$ & 32 & 6.27 & 1.843 & & \\
related to instrument & $20-21$ & 53 & 7.01 & 1.591 & 1.980 & .143 \\
performance & $22-23$ & 36 & 6.78 & 1.591 & & .156 \\
Mood felt during & $18-19$ & 32 & 5.85 & 1.781 & & 1.888 \\
instrument studies & $20-21$ & 53 & 6.53 & 1.629 & & \\
Modelling & $22-23$ & 36 & 5.97 & 1.926 & & .164 \\
& $18-19$ & 32 & 3.39 & 2.166 & & \\
\end{tabular}

The table indicates that the performance-related self-efficacy belief, mood felt during instrument work, and modelling self-efficacy levels of university students participating in the research did not significantly differ according to age group ( $p>0.05)$.

Table 4. Comparison of self-efficacy related to instrument performance scale points of university students according to the sex variable

\begin{tabular}{cccccccc}
\hline Subscale & Sex & $\mathrm{n}$ & $\mathrm{x}$ & $\mathrm{sd}$ & $\mathrm{t}$ & $\mathrm{p}$ \\
\hline Self-efficacy belief related to & Male & 52 & 7.10 & 1.576 & \multirow{2}{*}{.057} & .042 \\
instrument performance & Female & 69 & 6.48 & 1.707 & & \\
Mood felt during instrument & Male & 52 & 6.55 & 1.753 & 2.011 & .047 \\
studies & Female & 69 & 5.91 & 1.752 & & & \multirow{2}{*}{054} \\
Modelling & Male & 52 & 2.41 & 1.835 & \multirow{2}{*}{1.945} & .054 \\
& Female & 69 & 3.11 & 2.064 & & \\
\hline
\end{tabular}


From the table, it appears that modelling levels did not significantly differ according to the sex of the university students participating in the research $(p>0.05)$. Performance-related self-efficacy belief and mood felt during instrument work levels significantly differed according to sex $(p<0.05)$. The self-efficacy levels for performance-related self-efficacy beliefs and mood felt during instrument work of male students were higher.

Table 5. Comparison of self-efficacy related to instrument performance scale points of university students according to instrument group

\begin{tabular}{|c|c|c|c|c|c|c|c|}
\hline Subscale & $\begin{array}{l}\text { Individual } \\
\text { Instrument }\end{array}$ & $n$ & $x$ & sd & $f$ & $p$ & $\begin{array}{c}\text { Difference } \\
\text { between } \\
\text { groups }\end{array}$ \\
\hline \multirow{5}{*}{$\begin{array}{l}\text { Self-efficacy belief } \\
\text { related to instrument } \\
\text { performance }\end{array}$} & 1st group & 37 & 6.28 & 1.611 & \multirow{5}{*}{1.733} & \multirow{5}{*}{.147} & \multirow{5}{*}{-} \\
\hline & 2nd group & 39 & 6.89 & 1.566 & & & \\
\hline & 3rd group & 20 & 6.63 & 2.116 & & & \\
\hline & 4th group & 13 & 7.31 & 1.439 & & & \\
\hline & 5th group & 10 & 7.51 & 1.407 & & & \\
\hline \multirow{5}{*}{$\begin{array}{l}\text { Mood felt during } \\
\text { instrument studies }\end{array}$} & 1st group & 37 & 5.69 & 1.613 & \multirow{5}{*}{1.562} & \multirow{5}{*}{.189} & \multirow{5}{*}{-} \\
\hline & 2nd group & 39 & 6.37 & 1.740 & & & \\
\hline & 3rd group & 20 & 5.98 & 2.284 & & & \\
\hline & 4th group & 13 & 6.77 & 1.553 & & & \\
\hline & 5th group & 10 & 6.80 & 1.485 & & & \\
\hline \multirow{5}{*}{ Modelling } & 1st group & 37 & 2.85 & 1.651 & \multirow{5}{*}{.574} & \multirow{5}{*}{.682} & \multirow{5}{*}{-} \\
\hline & 2nd group & 39 & 2.52 & 1.905 & & & \\
\hline & 3rd group & 20 & 3.09 & 2.836 & & & \\
\hline & 4th group & 13 & 3.37 & 2.156 & & & \\
\hline & 5th group & 10 & 2.63 & 1.531 & & & \\
\hline
\end{tabular}

1st group (violin, viola, cello); 2nd group (guitar, bağlama); 3rd group (piano): 4th group (voice); 5th group (flute)

The table reveals that the performance-related self-efficacy belief, mood felt during instrument work, and modelling self-efficacy levels of university students participating in the research did not differ according to instrument played $(p>0.05)$. The total self-efficacy levels of students in the 4th instrument group (voice) were higher than those of students in the 1st group (violin, viola, cello).

Table 6. Comparison of self-efficacy related to instrument performance scale points of university students according to high school type

\begin{tabular}{|c|c|c|c|c|c|c|}
\hline Subscale & $\begin{array}{l}\text { High school } \\
\text { type }\end{array}$ & $\mathrm{n}$ & $x$ & sd & $\mathrm{t}$ & $p$ \\
\hline \multirow{2}{*}{$\begin{array}{c}\text { Self-efficacy belief related to } \\
\text { performance }\end{array}$} & Fine Arts & 67 & 7.03 & 1.505 & \multirow{2}{*}{2.077} & \multirow{2}{*}{.040} \\
\hline & Other & 54 & 6.40 & 1.819 & & \\
\hline \multirow{2}{*}{$\begin{array}{l}\text { Mood felt during instrument } \\
\text { studies }\end{array}$} & Fine Arts & 67 & 6.35 & 1.726 & \multirow{2}{*}{1.154} & \multirow{2}{*}{.251} \\
\hline & Other & 54 & 5.98 & 1.828 & & \\
\hline Modelling & $\begin{array}{c}\text { Fine Arts } \\
\text { Other }\end{array}$ & $\begin{array}{l}67 \\
54\end{array}$ & $\begin{array}{l}2.64 \\
3.02\end{array}$ & $\begin{array}{l}1.862 \\
2.141\end{array}$ & -1.043 & .299 \\
\hline
\end{tabular}

The table indicates that the mood felt during instrument work and modelling levels did not significantly differ according to the high school type for the university students participating in the research ( $p>0.05)$. Performance-related self-efficacy levels significantly differed according to high school type $(p<0.05)$. Students who had graduated from fine arts high schools had higher performance-related self-efficacy belief levels.

Table 7. Comparison of self-efficacy related to instrument performance scale points of university students according to perception of individual instrument quality 


\begin{tabular}{|c|c|c|c|c|c|c|c|}
\hline Subscale & $\begin{array}{c}\text { Quality } \\
\text { Perception }\end{array}$ & $n$ & $x$ & sd & $f$ & $p$ & $\begin{array}{c}\text { Difference } \\
\text { between } \\
\text { groups }\end{array}$ \\
\hline \multirow{3}{*}{$\begin{array}{l}\text { Self-efficacy belief } \\
\text { related to performance }\end{array}$} & $1-4$ & 11 & 5.21 & 1.701 & \multirow{3}{*}{14.998} & \multirow{3}{*}{.000} & \multirow{3}{*}{$\begin{array}{c}1<2,1<3 \\
2<3\end{array}$} \\
\hline & $5-7$ & 65 & 6.40 & 1.419 & & & \\
\hline & $8-10$ & 45 & 7.62 & 1.585 & & & \\
\hline \multirow{3}{*}{$\begin{array}{l}\text { Mood felt during } \\
\text { instrument studies }\end{array}$} & $1-4$ & 11 & 4.43 & 1.255 & \multirow{3}{*}{12.317} & \multirow{3}{*}{.000} & \multirow{3}{*}{$\begin{array}{c}1<2,1<3 \\
2<3\end{array}$} \\
\hline & $5-7$ & 65 & 5.94 & 1.482 & & & \\
\hline & $8-10$ & 45 & 6.97 & 1.884 & & & \\
\hline \multirow{3}{*}{ Modelling } & $1-4$ & 11 & 4.62 & 2.079 & \multirow{3}{*}{16.912} & \multirow{3}{*}{.000} & \multirow{3}{*}{$1>3,2>3$} \\
\hline & $5-7$ & 65 & 3.28 & 1.962 & & & \\
\hline & $8-10$ & 45 & 1.70 & 1.352 & & & \\
\hline
\end{tabular}

The table shows that performance-related self-efficacy beliefs, mood felt during instrument studies, and modelling self-efficacy levels significantly differed according to the perception of individual instrument quality of the university students participating in the research $(p<0.05)$. The performancerelated self-efficacy beliefs and mood felt during instrument work self-efficacy levels were significantly higher for those with instrument quality perception of 5-7 and 8-10 compared to those with instrument quality perception of 1-4. Additionally, the self-efficacy perception of those with instrument quality perception 8-10 was significantly higher compared to those with instrument quality perception of 5-7 $(p<0.05)$. For the modelling sub-dimension, those with instrument quality perception of 1-4 and 5-7 appeared to have significantly higher levels compared to those with instrument quality perception of 8 $10(p<0.05)$.

Table 8. Comparison of self-efficacy related to instrument performance scale points of university students according to previous solo concert performance

\begin{tabular}{|c|c|c|c|c|c|c|}
\hline Subscale & $\begin{array}{c}\text { Have you } \\
\text { performed a } \\
\text { solo concert? }\end{array}$ & $n$ & $x$ & sd & $\mathrm{t}$ & $p$ \\
\hline \multirow{2}{*}{$\begin{array}{l}\text { Self-efficacy belief related to } \\
\text { performance }\end{array}$} & Yes & 46 & 7.74 & 1.315 & \multirow[b]{2}{*}{5.783} & \multirow[b]{2}{*}{.000} \\
\hline & No & 75 & 6.13 & 1.581 & & \\
\hline \multirow{2}{*}{$\begin{array}{l}\text { Mood felt during instrument } \\
\text { studies }\end{array}$} & Yes & 46 & 7.10 & 1.611 & \multirow[b]{2}{*}{4.867} & \multirow[b]{2}{*}{.000} \\
\hline & No & 75 & 5.62 & 1.637 & & \\
\hline \multirow{3}{*}{ Modelling } & Yes & 46 & 1.73 & 1.495 & \multirow{3}{*}{-5.160} & \multirow{3}{*}{.000} \\
\hline & No & 75 & 3.48 & 1.974 & & \\
\hline & No & 75 & 5.19 & .972 & & \\
\hline
\end{tabular}

The table reveals that the performance-related self-efficacy beliefs, mood felt during instrument studies, and modelling self-efficacy levels were significantly different according to whether the students had performed solo concerts $(p<0.05)$. Students who had given solo concerts had higher performancerelated self-efficacy belief and mood felt during instrument studies, while those who had not showed higher modelling levels.

Table 9. Comparison of self-efficacy related to instrument performance scale points of university students according to earning money with their instrument

\begin{tabular}{ccccccc}
\hline Subscale & $\begin{array}{c}\text { Do you earn } \\
\text { money with } \\
\text { your } \\
\text { instrument? }\end{array}$ & $\mathrm{n}$ & $\mathrm{x}$ & $\mathrm{sd}$ & $\mathrm{t}$ & $\mathrm{p}$ \\
\hline $\begin{array}{c}\text { Self-efficacy belief } \\
\text { related to } \\
\text { performance }\end{array}$ & Yes & 39 & 7.94 & 1.115 & & \\
\hline
\end{tabular}




\begin{tabular}{ccccccc}
\hline Mood felt during & Yes & 39 & 7.33 & 1.367 & 5.437 & .000 \\
instrument studies & No & 82 & 5.64 & 1.691 & & \\
Modelling & Yes & 39 & 1.77 & 1.240 & \multirow{2}{*}{0.220} & .000 \\
\hline
\end{tabular}

The table shows that the performance-related self-efficacy belief, mood felt during instrument work, and modelling levels significantly differed according to whether the university students participating in the research earned money with their instrument or not $(p<0.05)$. The performance-related self-efficacy belief and mood felt during instrument work were higher for students earning money with their instrument, while the modelling levels of students who did not earn money with their instrument appeared to be higher.

Table 10. Comparison of self-efficacy related to instrument performance scale points of university students according to individual instrument lesson grade

\begin{tabular}{|c|c|c|c|c|c|c|c|}
\hline Subscale & Grade & $n$ & $x$ & sd & $f$ & $p$ & $\begin{array}{c}\text { Difference } \\
\text { between } \\
\text { groups }\end{array}$ \\
\hline \multirow{6}{*}{$\begin{array}{l}\text { Self-efficacy } \\
\text { belief related to } \\
\text { performance }\end{array}$} & $\begin{array}{l}\text { Less than } \\
50\end{array}$ & 8 & 5.00 & 1.624 & \multirow{6}{*}{27.715} & \multirow{6}{*}{.000} & \multirow{6}{*}{$\begin{array}{l}1<4,1<5, \\
1<6,2<4, \\
2<5,2<6\end{array}$} \\
\hline & $50-59$ & 11 & 4.54 & 1.273 & & & \\
\hline & $60-69$ & 15 & 5.81 & .956 & & & \\
\hline & 70-79 & 34 & 6.37 & 1.246 & & & \\
\hline & $80-89$ & 22 & 7.55 & 1.031 & & & \\
\hline & $90-100$ & 31 & 8.29 & 1.025 & & & \\
\hline \multirow{6}{*}{$\begin{array}{l}\text { Mood felt during } \\
\text { instrument } \\
\text { studies }\end{array}$} & $\begin{array}{l}\text { Less than } \\
50\end{array}$ & 8 & 5.06 & 1.585 & \multirow{6}{*}{17.569} & \multirow{6}{*}{.000} & \multirow{6}{*}{$\begin{array}{l}1<4,1<5, \\
1<6,2<4, \\
2<5,2<6\end{array}$} \\
\hline & 50-59 & 11 & 4.18 & 1.073 & & & \\
\hline & $60-69$ & 15 & 4.82 & 1.197 & & & \\
\hline & 70-79 & 34 & 5.89 & 1.404 & & & \\
\hline & $80-89$ & 22 & 6.91 & 1.392 & & & \\
\hline & $90-100$ & 31 & 7.65 & 1.406 & & & \\
\hline \multirow{6}{*}{ Modelling } & $\begin{array}{l}\text { Less than } \\
50\end{array}$ & 8 & 4.02 & 1.500 & \multirow{6}{*}{9.436} & \multirow{6}{*}{.000} & \multirow{6}{*}{$\begin{array}{l}1>4,1>5 \\
1>6,2>4 \\
2>5,2>6\end{array}$} \\
\hline & 50-59 & 11 & 5.09 & 1.089 & & & \\
\hline & $60-69$ & 15 & 3.19 & 1.955 & & & \\
\hline & 70-79 & 34 & 3.27 & 2.364 & & & \\
\hline & $80-89$ & 22 & 1.89 & 1.349 & & & \\
\hline & $90-100$ & 31 & 1.66 & 1.064 & & & \\
\hline
\end{tabular}

According to the table, the performance-related self-efficacy belief, mood felt during instrument work, and modelling self-efficacy levels significantly differed according to the individual instrument lesson grade of the university students participating in the research $(p<0.05)$. The self-efficacy perception for performance-related self-efficacy belief and mood felt during instrument work of those with lesson grades of 70-79, 80-89, and 90-100 appeared to be significantly higher compared to those with grades of less than $50,50-59$, and $60-69(p<0.05)$. For modelling, the proportion who felt they were inadequate with grades of less than 50 and 50-59 appeared to be significantly higher than for those with grades of 80-89 and $90-100(p<0.05)$.

\section{Discussion and conclusion}


Based on the findings obtained in the present research, it was concluded that the instrument performance-related self-efficacy scale points of students in the music education department did not significantly differ according to age group. A review of the literature shows that different results were revealed by similar studies. The study by Şentürk \& Bölek (2019) entitled "Investigation of Instrument Self-efficacy Status of Preservice Music Teachers" concluded that as year level, in other words age, increased, instrument self-efficacy belief increased. However, research entitled "Investigation of the Correlation between Academic Self-Efficacy Level and Attitudes to Instrument Studies of Preservice Music Teachers" by Şeker (2014) stated that as age increased, attitudes related to playing instruments displayed negative traits. Research by McCormick and McPherson (2003) entitled "The Role Of SelfEfficacy In A Musical Performance Examination: An Exploratory Structural Equation Analysis" found that self-efficacy was negatively affected among 332 instrumentalists attending Trinity College London with high levels in lower class levels that decreased due to the increasingly difficult exam requirements as the class level increased.

It was identified that the "modelling" level among the sub-dimensions of the instrument performance-related self-efficacy scale did not significantly differ with sex for students in the music teaching department. However, the self-efficacy levels of the other sub-dimensions of the scale, "performance-related self-efficacy belief" and "mood felt during instrument work", were in favour of males. A study by Özmenteş (2014) entitled "Correlations between Music Self-Efficacy, Self-Esteem and Individual Characteristics of Students Receiving Professional Music Education" identified that male students had higher self-efficacy perceptions compared to female students. The study entitled "Investigation of Professional Self-Efficacy Status of Preservice Music Teachers in terms of a Variety of Variables: The Selçuk University Example" by Birer and Sonsel (2013) identified a significant difference in ability to apply teaching methods self-efficacy perception levels in favour of male preservice music teachers. Research by Nielsen (2004) entitled "Strategies And Self-Efficacy Beliefs In Instrumental And Vocal Individual Practice: A Study Of Students In Higher Music Education" concluded that male students had higher self-efficacy belief levels due to greater participation in instrumental practice compared to female students.

It was concluded there was no significant difference in instrument performance-related self-efficacy scale points for the individual instrument variable among students in the music education department. However, students in the 4th group of individual instruments (voice) had higher self-efficacy levels compared to those in the 1st group (violin, viola, cello). Different results were found in the study entitled "Investigation of Instrument Self-Efficacy Status of Preservice Music Teachers" by Şentürk and Bölek (2019). When the mean points obtained from the instrument self-efficacy belief scale and subdimension of preservice music teachers were investigated according to instrument group, a positive significant difference was identified between the 1st and 3rd (violin, viola, cello, bass and guitar, bağlama, kanun) groups.

The sub-dimension levels for "mood felt during instrument studies" and "modelling" did not significantly differ for the high school type from which students in the music education department had graduated; however, the "performance-related self-efficacy belief" sub-dimension level did significantly differ. Students who had graduated from fine arts high schools were found to have higher "performance-related self-efficacy belief" levels. The study by Birer and Sonsel (2013) entitled "Investigation of Professional Self-Efficacy Status of Preservice Music Teachers in terms of a Variety of Variables: The Selçuk University Example" identified that the scale sub-factors of "command of the curriculum" and "self-efficacy perception related to educational level" were significantly different according to the high school type of preservice teachers in favour of those who had graduated from fine arts high schools. Preservice music teachers who had graduated from fine arts high schools considered themselves more competent in terms of their own educational level and knowledge of the curriculum. The study entitled "Investigation of Instrument Self-Efficacy Status of Preservice Music Teachers" by Şentürk and Bölek (2019) and the study entitled "Investigation of the Correlation between Academic Self-Efficacy Level and Attitudes to Instrument Studies of Preservice Music Teachers" by Şeker (2014) 
obtained results different from ours. Both of those studies stated there were no statistically significant differences in terms of instrument self-efficacy for fine arts high schools and other high schools.

It was identified that "performance-related self-efficacy belief", "mood felt during instrument work", and "modelling" self-efficacy levels, in other words all 3 sub-dimensions of the scale, significantly differed with the instrument quality perception variable for students in the music teaching department. The self-efficacy perception for the "performance-related self-efficacy belief" and "mood felt during instrument studies" sub-dimensions were higher for those with instrument quality perception of 5-7 and 8-10 compared to those with instrument quality perception of 1-4. This surprising result shows that students who considered their instrument was of higher quality felt they had higher self-efficacy levels. For students receiving voice training in individual instrument lessons, better perception of sound quality and sound interval are accepted as elements determining instrument quality. A review of the relevant literature revealed no finding or conclusion about the correlation of the individual instrument quality perception variable with self-efficacy levels.

It was identified that the self-efficacy levels for the 3 sub-dimensions of the scale significantly differed with the giving solo concerts variable for students in the music education department. Students who had given solo concerts had higher "performance-related self-efficacy belief" and "mood felt during instrument work", while students who had not appeared to have higher "modelling" levels. Studies by Şentürk and Bölek (2019), McCormick and McPherson (2003), and Nielsen (2004) support this result.

The self-efficacy levels for the 3 sub-dimensions of the scale significantly differed according to the earning money variable for students in the music teaching department. Students who earned money with their instruments had higher "performance-related self-efficacy belief" and "mood felt during instrument work" levels, while students who did not had higher "modelling" levels. Moving from here, giving solo concerts and earning money with instrument variables can be considered similar. The selfefficacy levels for the 3 sub-dimensions of the scale significantly differed according to the individual instrument lesson grade for students in the music education department. The self-efficacy perceptions for "performance-related self-efficacy belief" and "mood felt during instrument work" were significantly higher for those with grades of 70-79, 80-89, and 90-100 compared to those with grades of less than 50, 50-59, and 60-69.

\section{Recommendations}

It is considered that it will be beneficial to organize more individual concert activities during the education-teaching process to increase the instrument performance self-efficacy levels of students. According to the research results, another important element is the quality of the instrument. For this reason, quality instrument support may be provided by the educational organization for students without financial status to obtain a good instrument. Students who do not come from a fine arts high school can also be encouraged to participate in more concert activities. In addition, students' selfefficacy can also be taken into consideration when evaluating individual instrument lessons in institutions that educate music teachers. Similar studies may be performed with students of different ages and educational levels.

\section{References}

Afacan, Ş. (2008). Müzik Öğretimi Öz Yeterlilik Ölçeği. Ahi Evran Üniversitesi Kırşehir Eğitim Fakültesi Dergisi (KEFAD) 9(1),1-11. https://dergipark.org.tr/tr/pub/kefad/issue/59526/856042

Bandura, A. (1997). Self-efficacy: The Exercise of Control. New York; Freeman. 
Birer, A. R. H., \& Sonsel, Ö. B. (2013). Müzik öğretmeni adaylarının mesleki öz-yeterlik durumlarının çeşitli değişkenler açısından incelenmesi: Selçuk üniversitesi örneği. Fine Arts, 8(4), 389-398. http://dx.doi.org/10.12739/NWSA.2013.8.4.D0142

Büyüköztürk, Ş., Çakmak, E. K., Akgün, Ö. E., Karadeniz, Ş., \& Demirel F. (2009). Bilimsel Araştırma Yöntemleri. Ankara; Pegem Akademi.

Girgin, D. (2015). Çalgı performansı özyeterlik inancı ölçeği: Geçerlik ve güvenirlik analizi. Pamukkale Üniversitesi Eğitim Fakültesi Dergisi 38(38): 107-114. http://dx.doi.org/10.9779/PUJE701

Gün, E., \& Yıldız, G. (2014). Müzik öğretmeni adaylarına yönelik piyano performansı öz yeterlik ölçeğinin geliştirilmesi. Electronic Turkish Studies, 9(5), 1053-1065. http://dx.doi.org/10.7827/TurkishStudies.6896

Küçük, D. (2011). Müzik öğretmeni adaylarının müzik yeteneğine ilişkin özyeterlik algıları özel yetenek sınavı başarıları ve akademik başarıları arasındaki ilişki. Eğitim Bilimleri Dergisi, 34(34), 171-181. https://dergipark.org.tr/tr/pub/maruaebd/issue/376/2229

Mccormick, J., \& Mcpherson, G. (2003). The role of self-efficacy in a musical performance examination: an exploratory structural equation analysis. Psychology of Music, 31(1), 37-51. https://doi.org/10.1177/0305735603031001322

McPherson, G. E., \& McCormick, J. (2006). Self-efficacy and music performance. Psychology of Music, 34(3), 322336. https://doi.org/10.1177/0305735606064841

Nielsen, S. G. (2004). Strategies and self-efficacy beliefs in instrumental and vocal individual practice: a study of students in higher music education. Psychology of Music, Society for Education, Music and Psychology Research 32(4), 418-431.

https://doi.org/10.1177/0305735604046099

Özmenteş, S. (2011). Müzik öğretimine yönelik özyeterlik ölçeğinin geliştirilmesi. Journal of Educational and Instructional Studies in the World. 1(1), 30-36.

Özmenteş, G. (2014). Mesleki müzik eğitimi alan öğrencilerin müzik özyeterlikleri, benlik saygıları ve bireysel özellikleri arasındaki ilişkiler. Eğitim ve Bilim, 39, 171. http://egitimvebilim.ted.org.tr/index.php/EB/article/view/705

Pintrich, P.R., \& Schunk, D. H. (1996). Motivation in education: Theory, research and applications. Englewood Cliffs, NJ: Prentice-Hall.

Schunk, D. H., \& Pajares, F. (2009). Self-efficacy theory. In K. R. Wenzel \& A. Wigfield (Eds.), Educational psychology handbook series. Handbook of motivation at school pp. 35-53. New York. Routledge/Taylor \& Francis Group https://doi.org/10.4324/9780203879498

Silverman, M. (2008). A performer's creative processes: Implications for teaching and learning musical interpretation. Music Education Research, 10(2), 249-269.

http://dx.doi.org/10.1080/14613800802079114

StGeorge, J. (2006). The relationship of practice to continued participation in musical instrument learning. In Proceedings of the XXVIII ANZARME National Conference (pp. 189-199). Sydney, Australia: Monash University.

Şeker, S. S., \& Bilen, S. (2010). 9-11 yaş grubu çocuklarda orff schulwerk destekli keman eğitiminin keman çalmaya yönelik öz yeterlik algıları üzerindeki etkisi. Batı Anadolu Eğitim Bilimleri Dergisi, 1(2), 112-124. https://dergipark.org.tr/tr/pub/baebd/issue/3341/46242

Şeker S. S. (2014). Müzik öğretmeni adaylarının akademik özyeterlik düzeyleri ile çalgı çalışmaya ilişkin tutumları arasındaki ilişkinin incelenmesi, NWSA-Fine Arts 9(3): $135-149$. http://dx.doi.org/10.12739/NWSA.2014.9.3.D0155

Şeker, S. S. (2016). Development of instrument performance self-efficacy scale çalgı performansına ilişkin özyeterlik ölçeğinin geliştirilmesi. Journal of Human Sciences, 13(3), 5150-5162. https://doi.org/10.14687/jhs.v13i3.3933

Şentürk, G.C., \& Bölek, A. (2019). Müzik öğretmeni adaylarının çalgı öz yeterlik durumlarının incelenmesi. YYÜ Eğitim Fakültesi Dergisi (YYU Journal of Education Faculty) 16(1), 1110-1135. https://doi.org/10.33711/yyuefd.661547 
Thompson, L. (2007). Considering beliefs in learning to teach music. Music Educators Journal, 93(3), 30-35. https://doi.org/10.1177/002743210709300317

Welch, G. F., Himonides, E., Papageorgi, I., Saunders, J., Tettey, T.R., Stewart, C. \& Preti C, et al. (2009). The National Singing Programme for primary schools in England: An initial baseline study. Music Education Research, 11(1), 1-22. https://doi.org/10.1080/14613800802699523

Yıldırım, K. (2009). Kodaly yönteminin ilköğretim öğrencilerinin keman çalma becerisi, özyeterlik algısı ve keman çalmaya ilişkin tutumları üzerindeki etkisi. Yayımlanmamış yüksek lisans tezi. Dokuz Eylül Üniversitesi, Eğitim Bilimleri Enstitüsü, İzmir.

Yokuş, T. (2014). Müzik öğretmeni adaylarının eğitme-öğretme öz-yeterlikleri açısından değerlendirilmesi. Sanat Eğitimi Dergisi, 2(2), 43-56. https://doi.org/10.7816/sed-02-02-03

Zelenak, M. S. (2015). Measuring the sources of self-efficacy among secondary school music students. Journal of Research in Music Education, 62(4), 389-404. https://doi.org/10.1177/0022429414555018 